\title{
EDITORIAL ¿HACIA UNA SOCIEDAD DEL CONOCIMIENTO?
}

\author{
BEATRIZ PESCADOR VARgas MSC \\ Docente Biomédica - Facultad de Medicina. Universidad Militar Nueva Granada
}

\begin{abstract}
El conocimiento es el factor de desarrollo más importante en nuestro tiempo. Ya no se puede circunscribir solamente a los círculos académicos. Debe hacer parte de las agendas de gobiernos nacionales, regionales, locales y urbanos, de las organizaciones no gubernamentales, de los encargados de la salud, de los empresarios, de los gremios productores, de los ambientalistas, de los consultores. Impulsar la sociedad del conocimiento, desde la perspectiva del desarrollo territorial o regional, lleva implícita la convicción que si se guían y orientan, en esta dirección, las acciones de ciencia, tecnología e innovación y otras, se podrá lograr un impacto que se traducirá en mayor equilibrio, integración, sustentación y desarrollo social de las regiones.
\end{abstract}

El desarrollo de la cultura, la educación, la ciencia, la tecnología y la investigación, se han convertido en pieza fundamental del crecimiento económico y social de los países. Mejorar la calidad de la educación, dotar de herramientas a los estudiantes y docentes, capacitarlos en el desarrollo de nuevas y mejores habilidades, incentivarlos en la preparación de proyectos científicos e investigativos, crear los escenarios para que estén listos a enfrentar el nuevo mundo globalizado y permitir que alcancen su máxima potencia para que sean más competitivos en la construcción del tejido social al fomentar el sentido de pertenencia, la identidad cultural, el sano esparcimiento y así enfrentar la desigualdad y los conflictos, para crear una cultura de paz y humanista. La sociedad del conocimiento, entre varias alternativas, se puede caracterizar como aquella sociedad que cuenta con las capacidades para convertir el conocimiento en herramienta central para su propio beneficio.

Como afirma Faure (1973) "No basta reunir al Homo sapiens y el Homo faber, es preciso además, que se sienta en armonía con los demás y consigo mismo: Homo concors (...). Nuestro tiempo. Al que se ha llamado del mundo finito, no puede ser otro que el del hombre total; es decir, todo hombre y todo el hombre". En términos Delors
(1996), aprender a conocer, aprender a hacer y aprender a vivir juntos desde el conocimiento, lo que supone establecer que "el conocer" se constituye en un proceso fundamental, no solo para la educación, sino para la consolidación de sociedades capaces de autorregularse y superar sus problemáticas, lo cual exige a un hombre y a una mujer capaces de ser racionales y razonables, solidarios, participativos y responsables, ya no solo consigo mismos, sino en relación con los otros y con el entorno en el que habitan.

La sociedad del conocimiento puede ser mucho más inequitativa que la sociedad industrial capitalista tradicional. La potencialidad de exclusión que tiene la sociedad del conocimiento es enorme y lo hemos visto en las últimas décadas. Nuestro compromiso, con respecto a la construcción del saber, plantea la necesidad de trascender la producción de conocimiento per se y de posicionarse, en cambio en un escenario de producción de conocimiento con sentido social. La educación integral y la generación de conocimiento deben aportar a la transformación social y productiva del país, asegurando el desarrollo económico de país, porque una comunidad bien educada tendrá ventajas competitivas y podrá dar el salto a estándares de vida con más calidad. Los resultados del quehacer científico deberán ser orientados y aplicados a la solución de problemas específicos, considerando el impacto científico, social y ambiental de los métodos empleados y los productos obtenidos, útiles para el desarrollo.

En medio de todo esto está la tecnología como gran habilitadora de los procesos que permiten el desarrollo y la generación de oportunidades. Porque lo cierto es que la tecnología ha metido a la humanidad en nuevas relaciones con el mundo. La tecnología cambio la manera como interactuamos, como estudiamos, como nos comunicamos, como investigamos, como mercamos, como oímos música, como se brindan nuevos servicios a los ciudadanos y como se hacen los negocios. Porque la tecnología es 
el motor de muchos procesos de innovación. Y la innovación, volvemos a lo mismo, permite ampliar las oportunidades y ubicar a las comunidades en niveles altos de competencia. Con estos, hay que innovar, producir nuevas tecnologías, productos, materiales y aplicaciones, nuevas formas de hacer y de generar riqueza. Riqueza que conduzca a un mayor bienestar, incluyente, sostenible y con equidad, de todas las personas.

Los trabajos presentados en éste número, representan un aporte significativo al conocimiento, en donde la innovación en los diferentes procesos institucionales y la incorporación de las tecnologías de la información y las comunicaciones, permiten una mayor integración con los autores de la salud en el ámbito nacional y territorial; así como la conexión con los centros de investigación nacionales e internacionales del mundo.

"La política del Sistema de Ciencia, Tecnología e innovación de la Universidad Militar Nueva Granada (UMNG), es entrar a formar parte del grupo de Universidades que interactúan con el Estado y con el sector productivo en beneficio de la Sociedad Colombiana y del Sector Defensa, de acuerdo con las áreas temáticas, programas, procesos y grupos de investigación que actualmente posee, los cuales servirán de soporte a la implementación de estrategias de interacción y creación de redes colaborativas y de trabajo para cumplir objetivos comunes en el desarrollo de la Ciencia, la Tecnología y la Innovación". (Tomado de Sistema de Ciencia, Tecnología e Innovación $S C+T+I-U M N G$ 


\title{
EDITORIAL ¿TOWARDS A KNOWLEDGE SOCIETY?
}

\author{
Beatriz Pescador Vargas MSc \\ Teaching Biomedical - Faculty of Medicine. Universidad Militar Nueva Granada
}

Knowledge is the most important factor in the development in our time. It can no longer be circumscribed only to the academic circles. It must be a crucial matter in the national, regional, local and urban Government's agenda, of the non-governmental organizations, relevant to those related to health management, businessman, members of producer guilds, environmentalists and consultants. To promote the knowledge society, from the perspective of territorial and regional development, it has implicit the conviction that if it is well guided and oriented, towards that direction, science actions, technology and innovation among others could achieve an impact that will be translated in more equilibrium, integration, sustentation and social development of regions.

The appropriate development of culture, education, science, technology and investigation has turned into a fundamental piece of social and economical growth in all countries. Improving the quality of education, providing tools to students and teachers, training them in the development of new and better skills, encouraging them in the preparation of scientific and research projects, creating the scenarios for them to be ready to face the new globalized world and allow them to reach their maximum potential so that they are more competitive in the construction of social links by promoting the sense of belonging, cultural identity, healthy recreation and thus face inequality and conflicts to create a peaceful and humanitarian culture. The knowledge society, amongst several alternatives, can be characterized as that society that has the ability to transform knowledge into the main tool for their own benefit.

As stated by Faure (1973) "It is not enough to bring together the Homo sapiens and the Homo faber, it is also necessary to be in harmony with others and with himself: Homo concors (...). Our time. Which has been called the finite world, cannot be other than the one of the total man; this is every man and man as a whole". In Delors terms
(1996) learning to know, learning to do and learning to live together from knowledge, what supposes establishing that "knowing" is constituted into a fundamental process, not only for education, but for the consolidation of societies capable of self-regulation and overcoming their problems, which requires a man and a woman to be able of being rational and reasonable, to show solidarity, to be participative and responsible, not only with himselves, but in relation to others and the environment they inhabit.

Knowledge society can be much more inequitable than the traditional capitalist industrial society. The exclusion potential the knowledge society has is huge and we have seen it in the last decades. Our commitment, regarding the construction of knowledge, poses the need of transcending the production of knowledge per se and achieving certain position, instead of a stage of production of knowledge with social meaning. Integral education and knowledge generation must contribute to the social and productive transformation of the country, assuring its economical development, because a well educated community will have competitive advantages and could make the leap to life standards with more quality. Results of scientific work must be oriented and applied to the solution of specific problems, considering the scientific, social and environmental impact of the methods employed and the obtained products, useful for development.

Between all of this, technology is placed as the great enabler of processes that allow development and opportunity generation. The truth is that technology has taken humanity into new relations with the world. Technology has changed the way we interact, how we study, how we communicate, how we investigate, how we shop, how we listen to music, how new services are provided to citizens and how business are made. Because technology is the engine of many innovation processes. And innovation, back to the same, allows expanding opportunities and locating the communities with high competence levels. With these, 
there must be innovation, production of new technologies, products, materials and applications, new forms to do and generate wealth. Wealth that leads to a greater welfare, inclusive, sustainable and equitable to all people.

Papers presented in this number, represent a significant contribution to knowledge, where innovation in different institutional processes and the incorporation of technologies of information and communications, allowing a greater integration with national and territorial health authors; as well as the link between national and international research centers.
"The policy of the Science, Technology and Innovation of the Universidad Militar Nueva Granada (UMNG) is to be part of the group of Universities that interact with the State and the productive sector in benefit of Colombian Society and the Defense Sector, according to the thematic areas, programs, processes and research groups that actually it possesses, which will serve as support to the implementation of strategies of interaction and creation of cooperative and work networks to achieve common objectives in the development of Science, Technology and Innovation". (Taken from: Science, Technology and Innovation $\mathrm{SC}+\mathrm{T}+\mathrm{I}-\mathrm{UMNG})$ 


\title{
EDITORIAL
}

\section{¿RUMO UMA SOCIEDADE DO CONHECIMENTO?}

\author{
Beatriz Pescador Vargas MSC \\ Ensino Biomédica - Faculdade de Medicina. Universidad Militar Nueva Granada
}

\begin{abstract}
O conhecimento é o fator de desenvolvimento mais importante na época. Não é possível circunscreve-lo somente na área acadêmica. Deve fazer parte das agendas dos governos nacionais, regionais, locais e urbanos, das organizações não governamentais, dos encarregados da saúde, dos empresários, dos grêmios produtores, dos ambientalistas, dos consultores. Impulsar a sociedade do conhecimento, desde a perspectiva do desenvolvimento territorial ou regional, leva implícita a convicção do que se é guiada e orientada, nesta direção, as ações de ciência, tecnologia e inovação e outras, será possível um impacto que se traduzirá em maior equilíbrio, integração, sustentação y desenvolvimento social das regiões.
\end{abstract}

O desenvolvimento da cultura, a educação, a ciência, a tecnologia e a pesquisa, tem virado em uma peça fundamental do crescimento econômico e social dos países. Melhorar a qualidade da educação, dotar de ferramentas aos estudantes e professores, capacitá-los no desenvolvimento de novas y melhores habilidades, incentivá-los na preparação de projetos científicos e investigativos, criar os cenários para que fiquem prontos no enfrentamento do novo mundo globalizado e permitir atingir a máxima potencia com o fim de ser mais competitivos na construção do tecido social ao fomentar o sentido de pertinência, a identidade cultural, a correta recreação, enfrentando a desigualdade e os conflitos, criando uma cultura de paz y humanista. A sociedade do conhecimento, entre diversas alternativas, pode-se caracterizar como aquela sociedade que conta com as capacidades para virar o conhecimento em ferramenta central para o próprio beneficio.

Como afirmou Faure (1973) "Não é suficiente convidar ao Homo sapiens e ao Homo faber, é preciso, além, que estejam em harmonia com os outros e consigo mesmo: Homo concors (...). Nosso tempo. Ao que tem sido chamado do mundo finito, não pode ser outro do que o homem total; de fato, tudo homem e tudo o homem". Nos termos Delors (1996), aprender a conhecer, aprender a fazer e aprender a viver juntos desde o conhecimento, o qual supõe estabelecer que "o conhecer" constitui-se em um processo fundamental, não só para a educação, mas também para a consolidação de sociedades capacitadas para auto-regular e superar as problemáticas, o qual exige a um homem e a uma mulher capazes de ser racionais y razoáveis, solidários, participativos e responsáveis, não só pessoalmente, mas também com os outros e com o entorno.

A sociedade do conhecimento pode ser muito mais desigual do que a sociedade industrial capitalista tradicional. A potencialidade de exclusão que tem a sociedade do conhecimento é enorme e temos visto isto nas ultimas décadas. Nosso compromisso na construção do saber, levanta a possibilidade de transcender a produção de conhecimento per se y de se posicionar, em um cenário de produção de conhecimento com sentido social. A educação integral e a geração do conhecimento devem aportar à transformação social e produtiva do pais, assegurando o desenvolvimento econômico do pais, porque uma comunidade bem educada terá vantagens competitivas e poderá pular a uma vida com melhor qualidade. Os resultados do trabalho cientifico devem ser orientados e aplicados à solução dos problemas científicos, considerando o impacto cientifico, social e ambiental dos métodos utilizados e os produtos obtidos, uteis para o desenvolvimento.

No meio está a tecnologia como a grande habilitadora dos processos que permitem o desenvolvimento e a geração de oportunidades. A tecnologia tem juntado à humanidade com os novos relacionamentos do mundo. A tecnologia trocou o jeito de interação, de educação, da comunicação, da pesquisa, de comprar, de ouvir musica, da formar de dar novos serviços aos cidadãos e de fazer negócios. A tecnologia é o motor de muitos processos de inovação. E a inovação, de novo, permite ampliar as oportunidades e estabelecer às comunidades em níveis altos de competência. Com isso, há que inovar, produzir novas tecnologias, produtos, materiais 
y aplicações, novos jeitos de fazer e de gerar riqueza. Riqueza que atinge a um maior bem-estar, inclusivo, sustentável e com equidade, de todas as pessoas.

Os trabalhos apresentados neste numero, representam um aporte significativo ao conhecimento, onde a inovação nos diferentes processos institucionais e a incorporação das tecnologias da informação e as comunicações, permitem uma maior integração com os autores da saúde no âmbito nacional e territorial; além, como a conexão com os centros de pesquisa nacionais e internacionais do mundo.
"A política do Sistema de Ciência, Tecnologia e inovação da Universidade Militar Nueva Granada (UMNG) é formar parte do grupo de universidades que interatuamcom o estado e com o setorprodutivo em beneficio da sociedade Colombiana, e do setor defensa, de acordó com as áreas temáticas, programas, processos e grupos de pesquisa, os quaisvão servir de suporte à implementação de estratégias de interação e criação de redes colaborativas e do trabalho, com o fim de cumprir objetivos comuns no desenvolvimento da Ciência, a Tecnologia e a inovação. (baseado em: Sistema de Ciência, Tecnologia e Inovação" (SC+T+I - UMNG) 